near Olbia (on the question of the Roman building tradition in the Northwest Black Sea region)]. Arkheologichni doslidzhennia v Ukraini, 1, 48-54 [in Ukrainian].

Vinogradov, Yu.G. (1990). Olviia i Traian [Olbia and Trayan]. In: A.P. Novoseltsev (Ed.). Vostochnaia Evropa v drevnosti i srednevekove: problemy istochnikovedeniia. Tezisy dokladov (pp. 27-32). Moskva: In-t istorii SSSR [in Russian].

Zubar, V.M. (1998). Severnyi Pont i Rimskaia imperiia [Northern Pontus and the Roman Empire]. Kiev [in Russian].

Zubar, V.M. (2003). O nauchnoi etike R. Karasevicha-Shchiperskogo posviashchennoi rimskoi tsitadeli Khersonesa [About the scientific ethics of R. Karasevich-Shchipersky dedicated to the Roman citadel of Chersonesos]. Arkheologichni vidkrittia v Ukraini 2001-2002, 267-270 [in Russian].

\title{
КУЛЬТУРНА «МОДЕРНІЗАЦІЯ» УРБАНІЗОВАНИХ СПІЛЬНОТ
}

[рец.]: Прищепа О. «Місця зустрічі»: культурне довкілля міст Правобережної України (кінець XVIII - початок XX ст.): монографія. Рівне: М. Дятлов, 2019. 688 с.

\section{Ігор Кривошея}

Уманський державний педагогічний університет імені Павла Тичини (Умань, Україна) e-mail: igorkryvosheia@gmail.com ORCID: https://orcid.org/0000-0003-1429-8293

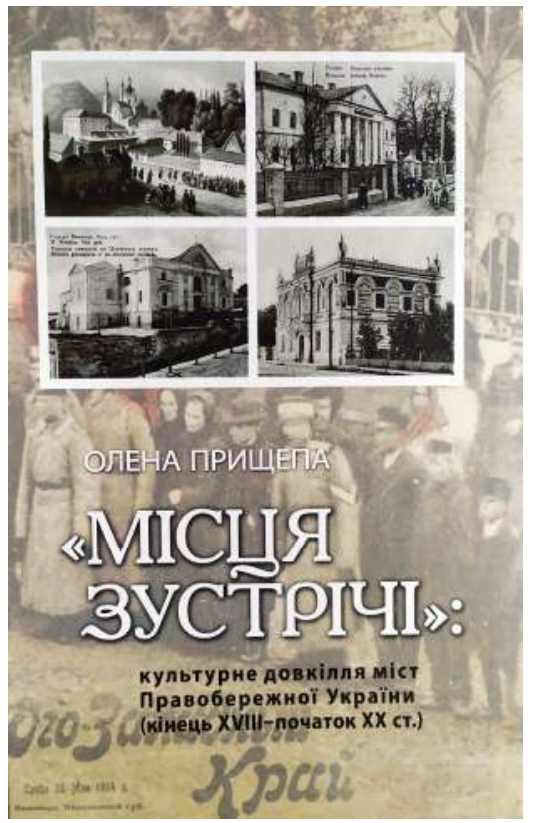

Історична урбаністика в Україні успішно розвивається. Свідченням цієї позитивної динаміки $€$ дослідження міських просторів і спільнот у монографії Олени Петрівни Прищепи, яку було опубліковано в 2019 р.

Текст монографії справляє позитивне враження. Реалізації окресленої проблематики сприяла структурно-логічна архітектоніка монографії як своєрідний фокус авторського замислу. Дослідження складається з передмови, вступу, чотирьох змістовних розділів, у яких здійснено аналіз найбільш важливих проблем і загалом успішно досягнута мета наукового пошуку, висновків, розлогих додатків (таблиць) і списку використаних джерел, а також іменного та географічного покажчиків.

Текст, запропонований читачеві, виважений i грунтується на широкій джерельній та історіографічній базі. Фактологічна база дослідження сприяє верифікації основних авторських положень, наповненню монографії науковою аргументацією й оригінальним фактичним матеріалом.

У першому розділі «Формування мережі освітньо-культурних закладів та осе- 
редків (остання чверть XVIII - перша чверть XIX ст.)» дослідниця показала, що після інкорпорації Правобережної України Російською імперією у регіоні зберігається система освіти, сформована ще за Речі Посполитої. Авторка наголошує, що в освіті домінували шляхетські традиції, які реалізовувалися як у стінах світських шкіл (Кременецький ліцей), так і в духовних училища (василіанські школи). Спроби царату, який тривалий час намагався «загравати» зі шляхтою, суттєво впливати чи регулювати освітньо-культурне середовище, по суті так і залишилися спробами аж до 1830 р. Тут варто зауважити, що в оточенні російських імператорів, особливо за часів Олександра I, було дуже досвідчене та потужне пропольське лобі.

Починаючи з першого розділу, через усю книгу проходить думка про позитивну, незважаючи на об'єктивні та суб’єктивні перешкоди, динаміку розвитку єврейської освіти та зростаючого впливу євреїв на культурне життя міст Правобережної України.

Другий розділ «Зміни культурного довкілля після листопадового повстання 1830 р.» охоплює широкий спектр змін, які відбувалися в освітньо-культурному середовищі у 30-х - початку 60-х років XIX ст.: вплив імперської політики у «польському» питанні на розвиток освіти й культури, формування приватних і громадських освітнього культурно-осередків, прояви опозиційності на фоні декласації правобережної шляхти 30-50-х років XIX ст.

Надзвичайно насиченим і складно структурованим вийшов в історика третій розділ «Прояви модернізації в освітньо-культурному середовищі між Січневим повстанням 1863 р. та революцією 1905 р.». Широке коло питань і проблем вдалося висвітлити Олені Петрівні у цьому розділі: реформування та розширення мережі освітніх закладів, зміни в освітній комунікації у школах, місію бібліотеки в освіті та міському просторі, активізацію міської інтелігенції та творення громадських товариств, які відігравали важливу роль у формуванні освітньо-культурного середовища урбанізованого простору. Дослідниця підкреслює особливу роль друкарень і періодичної преси, передусім газет, у творенні міської ідентичності урбанізованих спільнот.

Четвертий розділ «Трансформації освітньо-культурного середовища (19051917 рр.)» присвячено складним процесам, які відбувалися в містах у період між революціями та в умовах Першої світової війни. Окрім діяльності освітніх установ і культурних осередків, авторка також акцентує увагу на важливій ролі громадських товариств, що діяли у містах Правобережжя.

Підсумовуючи огляд монографії, зауважимо, що у монографії знайшли відображення процеси емансипації жінок у чоловічому суспільстві, підлітків у дорослому світі, вихідців із сільської місцевості в урбанізованому соціумі.

Висновки достатньо логічні та виважені, але, на жаль, невеликі за обсягом. Але при цьому кожен із чотирьох розділів завершується детальним узагальненням викладеного матеріалу, i, напевне, саме тому дослідниця вирішила не дублювати їх у загальних висновках.

Таблиці суттєво доповнюють текст монографії, є доречними й інформативними для того, щоб у читача склалася цілісна картина освітньо-культурного середовища міст Правобережної України імперської доби. Бібліографія (архівні джерела, періодична преса, монографії, статті тощо), яку використовувала вчена, вміщена на 70 сторінках, що є ще одним доказом копіткої та наполегливої праці Олени Прищепи. Позитивним, на нашу думку, є вміщення summary англійською мовою. 
Разом із тим відзначаємо, що авторці варто було б приділити дещо більше уваги освіті жінок у першій третині XIX ст., зокрема тих, хто навчався у приватних пансіонах. Потребує також, на нашу думку, більшого висвітлення роль нових освітніх закладів у культурному розвитку міст. Наприклад, таких як: Політехнічний інститут у Києві, або Головне училище садівництва/Уманське училище землеробства i садівництва (Одеса-Умань) та ін.

Насамкінець хотілося б зауважити, що монографія рівненської дослідниці Олени Прищепи справляє враження грунтовної та серйозної праці, яка дає імпульс для подальших наукових пошуків у сфері історичної урбаністики. Книжка зацікавить усіх, хто прагне долучитися до дослідження міських просторів і спільнот. 